Women, Employment and Development in the Arab World 


\section{New Babylon}

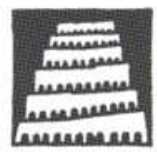

Studies in the Social Sciences

41

MOUTON PUBLISHERS - BERLIN - NEW YORK - AMSTERDAM 


\section{Women, Employment and Development in the Arab World}

Edited by

Julinda Abu Nasr,

Nabil F. Khoury

and Henry T. Azzam

This volume was prepared with the assistance of the International Labour Office, the Institute for Women's Studies in the Arab World (Beirut), and the United Nations Fund for Population Activities.

International Labour Organisation
Regional Office for Arab States

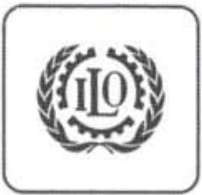

Labour and Population Team Middle East and Mediterranean Region
Beirut University College

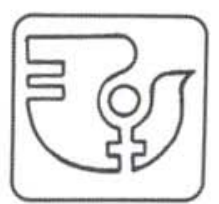

Institute for Women's Studies in the Arab World 
Women, employment, and development in the Arab world.

(New Babylon, studies in the social sciences ; 41)

1. Women - Employment - Arab countries - Addresses, essays, lectures. I. Abu Nasr, Julinda. II. Khoury, Nabil F., 1948- . III. Azzam, Henry T., 1948- IV. Series.

HD68 6.W66 1984

$331.4^{\prime} 0917^{\prime} 4927$

84-9935

ISBN 90-279-3380-4

Printed on acid free paper

(pH 7, neutral)

(c) Copyright 1985 by Walter de Gruyter \& Co., Berlin. All rights reserved, including those of translation into foreign languages. No part of this book may be reproduced in any form - by photoprint, microfilm, or any other means - nor transmitted nor translated into a machine language without written permission from the publisher. Typesetting: Asian Research Service, Hong Kong. Printing: Druckerei Hildebrand, Berlin. - Binding: Dieter Mikolai, Berlin. 